\title{
Designing Scientific Writing Materials Using Task Based Language Teaching
}

\author{
Testiana Deni Wijayatiningsih ${ }^{1}$, \\ Enny Dwi Lestariningsih ${ }^{2}$, \\ Dwi Ampuni Agustina ${ }^{3}$ \\ ${ }^{1)}$ Universitas Muhammadiyah Semarang, \\ ${ }^{2,3)}$ Universitas Terbuka UPBJJ-UT Semarang \\ 1)testiana@unimus.ac.id
}

Article History: Submitted December 4, 2018; Accepted December 9, 2018; Published December 10, 2018

\begin{abstract}
One of the consequences of teachers as functional positions is that teachers are required to carry out continuous professional development (PKB), so they can carry out their duties and functions professionally. Continuous professional development is the development of teacher competencies carried out in accordance with the needs, gradually, continuously to improve their professionalism; one of them is scientific publication (KTI) or academic writing. This study aims to determine the process of designing the Task Based Language Teaching method in scientific writing material and examine the learning outcomes of elementary school teachers who take tutorial courses on Scientific Work Writing Techniques based on Task Based Language Learning. The subjects of this study were students who took the eight semester of Scientific Writing Techniques course. The method of this research used the modified 4-D instructional development model of Thiagarajan, Semmel and Semmel (4-D models). The methods of collecting data used interviewing, observing, test, and filling out questionnaires. The results shows that the application of the Task Based Language Teaching method is appropriate to use in classroom tutorial teaching by considering the results of validation, namely conformity to concept indicators, content feasibility indicators, presentation indicators, and competency indicators with existing RAT and SAT along with Engineering learning modules Writing Scientific Work. Furthermore, students' self-concept is good in learning the Scientific Writing Technique in the tutorial class. This means that students' self-concept had a good improvement and reached a percentage above $70 \%$. This proves that the application of the Task Based Language Teaching method runs seamlessly and according to what is expected. All in all, the students are more enthusiastic and challenging in writing research articles.
\end{abstract}

Keywords: task based language teaching, scientific writing, materials 


\begin{abstract}
ABSTRAK
Salab satu konsekuensi guru sebagai posisi fungsional adalah guru dituntut untuk. melakukan pengembangan profesi berkelanjutan (PKB), sehingga mereka dapat menjalankan tugas dan fungsinya secara profesional. Pengembangan profesional berkelanjutan adalah pengembangan kompetensi guru yang dilakukan sesuai dengan kebutuban, secara bertahap, terus menerus untuk meningkatkan profesionalisme mereka; salah satunya adalah publikasi ilmiah (KTI) atau tulisan akademik. Penelitian ini bertujuan untuk mengetahui proses merancang metode Pengajaran Bahasa Berbasis Tugas dalam materi penulisan ilmiah dan menguji hasil belajar guru sekolah dasar yang mengambil kursus tutorial tentang Teknik Penulisan Karya Ilmiab berdasarkan Tugas Berbasis Babasa Pembelajaran. Subyek penelitian ini adalah mahasiswa yang menempuh kursus teknik penulisan ilmiah selama delapan semester. Metode penelitian ini menggunakan model pengembangan instruksional 4-D yang dimodifikasi dari Thiagarajan, Semmel dan Semmel (model 4-D). Metode pengumpulan data menggunakan wawancara, observasi, tes, dan pengisian kuesioner. Hasil penelitian menunjukkan bahwa penerapan metode Pengajaran Babasa Berbasis Tugas sesuai untuk digunakan dalam pengajaran tutorial kelas dengan mempertimbangkan hasil validasi, yaitu kesesuaian dengan indikator konsep, indikator kelayakan konten, indikator presentasi, dan indikator kompetensi dengan TIK dan SAT yang ada di sepanjang dengan modul pembelajaran Teknik. Menulis Karya Ilmiah. Selanjutnya, konsep diri siswa baik dalam mempelajari Teknik Penulisan Ilmiah di kelas tutorial. Ini berarti konsep diri siswa mengalami peningkatan yang baik dan mencapai persentase di atas 70\%. Ini membuktikan bahwa penerapan metode Pengajaran Babasa Berbasis Tugas berjalan dengan lancar dan sesuai dengan apa yang dibarapkan. Kemudian, respon motivasi siswa dalam kelas tutorial setelah diterapkan memiliki peningkatan motivasi yang baik dan mencapai persentase di atas $70 \%$ dalam pembelajaran tutorial dan mereka lebih antusias dalam proses belajar mengajar.
\end{abstract}

Kata kunci: Pengajaran Bahasa berbasis Tugas, penulisan karya Ilmiah, bahan ajar

\title{
INTRODUCTION
}

The teacher is a professional educator with the main task of educating, teaching, guiding, directing, training, evaluating, and evaluating students in early childhood education in formal education, basic education, and secondary education. One of the consequences of teachers as functional positions is that teachers are required to carry out continuous professional development (PKB) so that teachers can carry out their duties and functions professionally. Continuous professional development is the development of teacher competencies carried out in accordance with the needs, gradually, continuously to improve their professionalism; one of them is scientific journal publication (KTI). Writing scientific papers for teachers can be the references to improve insight or disseminate knowledge. 
Writing scientific papers will be useful in improving reading and writing skills, practicing integrating various ideas and presenting them systematically, broadening horizons, and providing intellectual satisfaction, while contributing to the expansion of the horizons of science. Papers that have been made by a teacher need to be presented in a scientific forum such as; seminars, workshops, symposia or conferences. Besides being presented in scientific forums, papers or articles can also be published in scientific journals periodicals.

In contrast, in reality teachers focus more on classroom learning, administrative preparation, assessment, and matters relating to teaching. This is where many teachers forget their duty to write scientific works. This happened to students who came from teachers who continued their PGSD undergraduate education. They tend to be confused in determining the topic of their research, then do not understand the flow of research or scientific work which is worthy of being the result of developing their own competencies.

Because of the problems above, we tried to designing the Task Based Language Learning method in scientific writing material. The development and design of material and assignments is expected to motivate students to be able to compile scientific work based on the Task Based Language Teaching method. Based on the initial observations of the research team, students who took the course of Scientific Writing Engineering tended to be confused in summarizing the results of the report Strengthening Professional Capabilities into a scientific work that is worthy of publication both online and not. Furthermore, the low motivation of students to write scientific papers triggers difficulties in compiling coherent sentences per sentence. In addition, the tendency of students to see models from senior students who have taken the course is very numerous. The method of writing interesting scientific work, teaching techniques that are suitable for the classroom atmosphere, applicable media, and teaching materials based on Task Based Language Teaching are considered to support the creation of scientific work in the form of articles uploaded on UT's online digital library pages.

Based on the problems above, we need to design the interesting teaching materials and support the design of their respective scientific works, namely through the Task Based Language Learning method.

Based on the results of the observations, we can conclude the obstacles faced by students when preparing scientific papers to be published, namely the lack of motivation to publish research results in the form of articles or reviews from a book. Other observations were also found in the low understanding of students in designing scientific works 
that would later be published online and printed both in terms of language, topics, and the selection of interesting scientific articles so that many intellectual or non-intellectual communities were interested in reading and adopting the results of the research expressed in scientific article.

In line with the complex problems above, it is necessary to do reflection and changes to the right teaching methods that make the implementation of student tutorials more active and effective.

Changes and reflections are carried out through the application of the Task Based Language Teaching method to the material of scientific writing as a stimulus, so the students are more active and creative in compiling scientific works that are well published online and in print.

\section{Research Questions}

Based on the description of the obstacles faced above, we can formulate the problem as follows: a. How is the process of designing the Task Based Language Learning method in scientific writing material? b. Does the application of the Task Based Language Learning method improve the learning outcomes of elementary school teachers who take courses in scientific writing techniques?

\section{Task Based Language Teaching (TBLT)}

TBLT method provides learners the opportunity to be able to exchange knowledge in pairs or groups, this is also called talk on task and off task. On task talk is the conversation that is used related to matters relating to learning. Conversely, off task talk is talk that is not related to learning, such as chatting, joking, etc. Task-Based Language Teaching (TBLT) is one method of teaching students that focuses on students, TaskBased Language Teaching (TBLT) is a language teaching system that focuses on the tasks given to students. The tasks (questions) given to students are central to language teaching activities. Empirically it can be said that giving problems or problems to students will be a benchmark for students' abilities and understanding of a material (Richards 2001).

According to Richards \& Rodgers (2001) Task-Based Language Teaching (TBLT) is a language teaching method that uses tasks as a core unit to plan and compile instructional materials in language teaching. In other words, the main subject of language teaching is the use of tasks as a way to achieve teaching goals. Based on the TBLT definition above, Nunan (2005) distinguishes tasks in two types, namely: tasks as targets and pedagogical tasks. The task as a target refers to the use of language in daily 
activities outside the teaching-learning realm, while the pedagogical task refers to the use of language in the teaching-learning process in the classroom in the form of assignments or exercises in the classroom with context and relating to real life.

Ellis (2003) further emphasizes that the task as a work plan (learning) consists of: (1) some input or information where the learner is required to implement it, and (2) the instructional objectives reflect the results that must be achieved by the learner. In other words, tasks as a work plan have four characteristics. First, the assignment emphasizes the acquisition of language meaning rather than the acquisition of language rules. Second, assignments require learners to gain communicative abilities as goals and learning outcomes. Third, the task of improving linguistic abilities through the context of natural communication. Fourth, assignments are designed as classroom activities related to daily activities. Oxford (2006) states that there are three perspectives of pedagogic tasks in the learning process of the second language. First, the task functions as a general activity or exercise from the second language. In this perspective, the teacher uses and discusses the exercises or tasks in the textbook as class assignments without emphasizing learning outcomes (values).

Second, the task of describing instructional objectives is oriented towards the results of second language learning. This perspective focuses on learners completing the demands of curriculum content through teacher teaching procedures. Third, the task is a classroom learning behavior framework. This perspective considers the task as a planned activity for learners to obtain learning while displaying language skills. Although these three perspectives seem to support the use of language, assignments are still regarded as activities that force learners to develop both language skills. Although assumed to be coercive, assignments are still considered useful to facilitate learners in learning aspects of language, increasing their motivation to speak, and promoting their ability to negotiate meaning when communicating and collaborating with other learners (Hatip, 2005).

Therefore, Hatip (2005) states that there are six types of tasks that are considered to support the success of language learning, namely:

1. Sort (listing)

2. In this type, learners are involved in the process of idea and fact finding.

3. Arranging and Sorting (ordering and sorting)

4. In this type, learners are involved in the process of sorting, ranking, categorizing, and classifying various things in different ways.

5. Comparing 
6. In this type learners learn to identify the main points of certain information from different sources by activating the matching process and seeing the similarities and differences of the information.

7. Solve problems (problem solving)

8. In this type, learners are involved in the process of analyzing real situations or hypotheses only, weighing reasons and making decisions.

9. Sharing personal experiences (sharing personal experiences)

10. In this type, learners are required to activate their ability to narrate, describe, explain attitudes and opinions and respond to various opinions.

11. Creative tasks

12. This type of task includes a combination of types of sorting, organizing and sorting, comparing and solving problems. In this type, learning learners display their abilities through various types of tasks.Skehan (1998) as quoted by Ellis (2003) states those pedagogic tasks as a work plan (learning) have four main characteristics. First, the meaning of the language expressed is important and a priority. Second, there are goals that must be achieved from the tasks given. Third, the design of learning activities on the given task must be evaluated for results. Fourth, the design of learning activities must be related to daily activities. The four characteristics clearly emphasize the acquisition of the meaning of the language used must be in accordance with the context and related to real life.

In general, assignments to students can be said to be the basic concept of TBLT. But in this case the assignment of students at the beginning of the material or meeting is a characteristic of this method. Of the various experiences that are often experienced by teachers is, when given a new material, the teacher will do a lot of elaboration to embed a concept into the minds of students.

However, in TBLT, students will be required to first understand the material to be delivered and after that the conceptualization of the teacher will be limited to true or false assessments. With this method the role of the teacher as a supervisor will be more optimized. In short, task-based language teaching allows students to produce target language through communicative task completion.

In addition, the principles of Task Based Language Teaching according to Robinson (2011) that can facilitate the SLA process are as follows; the task must have a context to negotiate and it can be understood its meaning, the assignment given can be explained implicitly or explicitly and has production feedback from the participant, by a partner, or by a teacher, the assignment can be modified inputs and have positive evidence to be more communicative, the assignment can pay attention to the gap (noticing gap) between production and input given by participants and 
output as a metalinguistic reflection, the task must be able to focus on specific concepts needed for language learning and quick efforts to understand their grammar, assignments a simple one that can be used as access to improve language fluency and automation will emerge if it is used to fulfill demands with consequences to improve production fluency, tasks can also be reconceptualizing and recall / recalling events, conceptual ways realization as a learning process, assignments must have a sequence of problem solving that can strengthen memory for learner participants, and assignments given must be adapted from a simple version, then complex tasks so that students try to be more ambitious, using complex language so that the solution task demands are more communicative / syntactic priming (Boston, 2010). In addition, the task designed must be able to foster the motivation of students to learn.

In conclusion, the use of TBLT can represent what is in the real world can be practiced as much as possible in the classroom. The goal is when students can reach the target of learning in the classroom can be applied in the real world, and this is considered very effective. As the results of the research of Ahmed and Bidin (2016) conducted in Malaysia which stated that the use of the TBLT method was very positive for students in learning English both in the classroom and in the real world. There are also results from Hu's (2013) research conducted in Beijing, China, which recommends the TBLT method is very appropriate and can be implemented in all levels for teaching English. The TBLT framework according to Nunan (2005) in the figure below.

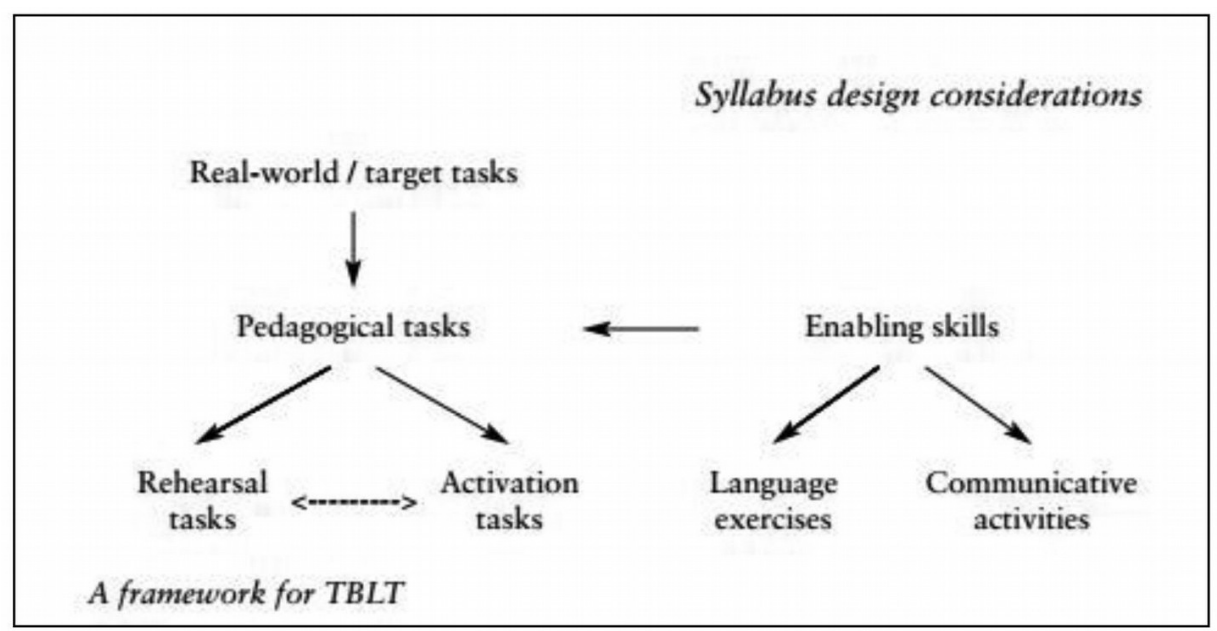

Nunan (2005)

Scaffolding is inviting and teaching students to read in the first place so as to create the concept of critical thinking as taught. Second, Task Dependency is the exercise given must be related to before and after so 
there is a measure of the development of the level of teaching. Third, Recycling is the spinning and consistent learning. Fourth, Active Learning is that students are required to learn actively or student learning centers and tutors apply as facilitators. Fifth, Integration, which is the material taught, can be integrated in other words, for example, given an essay training but can at the same time learn to write scientific work. Sixth, Reproduction to Creation is the students are directed to be able to produce maximally what is learned. Finally, Reflection is the students are given the opportunity to be able to reflect on what has been learned and the extent of the theory of scientific work that has been owned.

\section{Writing}

The ability to write is a very important part of mastering the language. Writing is an attempt to make or re-write an existing one (Barli, 2002). It means that writing is an activity to create a record or information on a media using letters. Writing is usually done on paper by using tools such as pens or pencils. In line with the above understanding Hyland (2004) states that writing is an ability that is supported by situations, conditions, and instructors who provide support but do not interfere directly. Boardman (2002) adds that repetitive processes that start from planning, organizing, then writing, editing, revising, and final writing are called writing. From all the statements above it can be concluded that writing is an integrated and sequential part that requires vocabulary and the ability to compose words into sentences, sentences being paragraphs that make up the text.

\section{Scientific Work}

Scientific work is a writing that contains a study of a particular problem using scientific rules. Scientific rules include the use of scientific methods and the fulfillment of scientific principles, such as: objective, logical, empirical, systematic, straightforward, clear, and consistent. Scientific works can be divided into two, (i) scientific works written based on the results of research, and (ii) scientific works written based on the results of serious thought. Both types (i) and (ii), in writing still use the problem analysis method that is approaching the truth (scientific).

Scientific works are essays of science that present facts and are written according to good and correct writing methodologies (Haryanto, 2000). 


\section{Research Framework}

The hypothesis of this study is generated through the Task Based Language Teaching method on valid scientific writing material, with indicators: a. describing the process of designing the Task Based Language Teaching method on scientific writing material for elementary school teachers. b. examining the learning outcomes of elementary school teachers who took the course tutorial on Scientific Works Writing Technique on the application of the Task Based Language Teaching method. c. Research student activity in the tutorial process on the application of the Task Based Language Teaching method to scientific writing material.

\section{METHOD}

The subject of this research was PGSD students who took the UPBJJ-UT Scientific Writing Techniques course in the 8th semester of 2018 which consisted of 20 people in the Kaliwungu Kendal. This study used research and development methods whose its goal is finally to form a valid product and measure the effectiveness of the application of the product. The development uses the 4-D method of developing the modified Thiagarajan, Semmel and Semmel instructional systems (4-D models). This development model consists of define (design), design (design), develop (development), disseminate (spread). In this study a modification of the 4-D model was carried out, namely simplification of four stages into three stages, namely, Define (definition), Design (design), Develop (development). Disseminate is not done due to time and implementation considerations and consideration that the development (validation) has produced a valid device.

The data collection of this study uses the following methods: 1 . Interview According to Sugiyono (2011) the interview is used as a method of collecting data if a preliminary study is conducted to find and look for the problems being studied. Interviews were conducted with students to obtain mastery level data about the material of scientific writing before and after the study. 2. Questionnaire The researcher used a questionnaire to obtain information about student responses after participating in activities using textbooks as a result of development. 3. Observation Observations were made to obtain information about the learning outcomes of scientific writing on field trials using the learning tools developed. In addition, the observation method was also conducted to determine the validity of learning devices with a checklist technique. 
This research is said to be successful if:

a) The learning devices are considered valid if the score of the validator or expert is in the category of good or very good.

b) The average ability of students to master the concept of scientific writing material reaches $70 \%$.

c) The average ability to write scientific papers reaches $70 \%$.

d) At least $70 \%$ of the number of students gives a positive response to the learning done.

\section{FINDINGS AND DISCUSSION}

\section{Findings}

This study had some results which described into some stages below.

\section{Define Stage (Defining)}

This defining stage aims to define and define learning needs by analyzing the goals and boundaries of the material. The activities in define this include analysis of material needs and assignments of students through tutor discussions with observers from UPBJJ, analysis of indicators, analysis of learning characteristics with the Task Based Language Teaching method on scientific writing material, analysis of concepts, task analysis, analysis of students, research studies relevant to answering existing problems and literature studies on supporting theories.

\section{Stage Design}

This stage has the purpose of designing teaching devices so as to produce a form of teaching material design based on the Task Based Language Teaching method on scientific writing material. The results of this design phase are hereinafter referred to as draft 1.

\section{Stage Develop (Development)}

The purpose of this stage is to produce a draft of a good teaching device. Activities at this stage include validation of small trials and field trials. The explanation of this stage is as follows;

a. Expert validation is done to get suggestions for improvement as well as an assessment of experts (validators) on the design of teaching device instruments based on the Task Based Language Teaching method on scientific writing material (draft 1). Validation of learning device 
instruments and teaching materials based on the Task Based Language Teaching method on scientific writing material is carried out by experts in their fields. Based on the results of expert validation, revisions to the devices and instruments were carried out so as to produce a draft 2 that was feasible to use. The results can be seen in the table below.

Table 1:

The Validation Results from Experts

\begin{tabular}{llllll}
\multirow{2}{*}{ No } & Validator & \multicolumn{4}{c}{ The Validation Average } \\
\cline { 3 - 6 } & & RAT & SAT & $\begin{array}{c}\text { Teaching } \\
\text { Materials }\end{array}$ & TTM \\
\hline 1 & 1 & 4,31 & 4,13 & 4,10 & 4,11 \\
2 & 2 & 4,08 & 4,00 & 4,10 & 4,00 \\
& Criteria & Valid & Valid & Valid & Valid \\
\hline
\end{tabular}

Based on the table above it can be concluded that the results of the average RAT, SAT, teaching material, and independent tutorial assignments are valid because they have reached criteria 4 . Therefore, the RAT \& SAT instrument, teaching materials, independent tutorial assignments can be used properly in learning Scientific Works Writing Techniques that use the Task Based Language Teaching method. In addition, there are things that need to be considered, namely the clarity of teaching material indicators in relation to the application of the Task Based Language Teaching method, referring to seven principles. From the suggestion, the researcher then revised the results of the teaching material by adding a description of the teaching material which explained what the teaching material was about and what the objectives were, as well as adding procedures for writing scientific papers or proposals using the PTK method whereas for RAT \& SAT it is feasible to use because it has included the application of the Task Based Language Teaching method.

b. Test the closed interview sheet that will be used at the field trial stage. Trials of interview sheets were given to PGSD students who had taken courses in Scientific Works writing techniques. A small trial is conducted to reflect the learning device that has been validated (draft 2).

c. The simulation results in the small trial class were analyzed and revised to obtain teaching materials based on the Task Based Language Teaching method on scientific writing material to be used for field testing (draft 3). The results of the reliability analysis indicate that the questions in the motivation questionnaire questionnaire have entered into the reliable category. This is evidenced by the reliability calculation using the following formula; 
$\mathrm{r}_{\mathrm{xy}}=\frac{\mathrm{N} \Sigma \mathrm{XY}-(\Sigma \mathrm{X})(\Sigma \mathrm{Y})}{\sqrt{\left\{\mathrm{N} \Sigma \mathrm{X}^{2}-(\Sigma \mathrm{X})^{2}\right)\left\{\mathrm{N} \Sigma \mathrm{Y}^{2}-(\Sigma \mathrm{Y})^{2}\right\}}}$

(Arikunto, 2009)

From the results of calculations using the formula above, the results of the question validity in the motivation of students that the number of questions in the questionnaire are 15 questions, then valid, there are 10 questions which lie in the questions number 1,2,4,5,6,9,11,12, 14 , and 15 . From these results it can be concluded that only 10 questions will be used in this study because only 10 are valid. The results of the questionnaire data reliability are at 0.712 , which means that the question can be used in research.

d. Field trials Trial revised learning device (draft 3) is done in the tutorial class. At the end of the meeting students were also given a questionnaire to find out the response of students to the use of teaching materials based on the Task Based Language Teaching method on scientific writing material that had been developed. During teaching and learning researchers are accompanied by observers who observe student activities. After learning, researchers and observers reflect on the activities that have been carried out. Reflection results are used to base the revision of learning devices so that learning devices are obtained from the development results.

From these data, it can be concluded that student motivation increased from before the Task Based Language Teaching application on teaching materials and learning devices in the tutorial class. This is known from the results of observations and student motivation questionnaires. They tend to be enthusiastic in writing and summarizing PTK reports into weighty scientific articles that deserve to be uploaded because they are written using the collaborative Task Based Language Teaching method so that they are more skilled at summarizing and active in writing weighty scientific articles specifically using classroom action research. This means that the Task Based Language Teaching application in learning and teaching materials is feasible to be used in learning subjects in Scientific Writing Techniques. b). Student learning outcomes before and after the application of teaching materials, RAT, SAT, and learning tools Task Based Language Teaching The results of the independent tutorial assignment assessment have increased success in answering questions and analyzing the problems presented by the tutor with Task Based Language Teaching based on the average score of $70 \%$ pre test increasing to $85 \%$. This means that students experience increased ability to understand and apply Task Based Language Teaching. 


\section{Discussion}

From the results of the above research, results can be obtained that the application of the Task Based Language Teaching method is appropriate to use in learning Scientific Works Writing Techniques. This result is proven by the results of research stating that the results of the validation of the Task Based Language Teaching method specifically using teaching materials are appropriate to use in classroom tutorial teaching taking into account the results of validation, namely conformity to concept indicators, content eligibility indicators, presentation indicators, and indicators competency with the existing RAT and SAT along with the PTK tutorial learning module. In addition, the application of the Task Based Language Teaching method can invite them to think critically and applicatively to compile scientific articles that are worth uploading online. Furthermore, the scientific articles produced by the students trace the seven principles (TBLT) of the Task Based Language Teaching method, namely Scaffolding by inviting and teaching students to read the most fluent so that they create the concept of critical thinking as taught. Second, Task Dependency, namely the exercise given must be related to before and after so there is a measure of the development of the level of teaching. Third, Recycling with spinning and consistent learning. Fourth, Active Learning is that students are required to learn actively or student learning centers and tutors apply as facilitators. Fifth, Integration, which is the material taught, can be integrated in other words, for example, given an essay training but can at the same time learn to write scientific work. Sixth, Reproduction to Creation, namely students are directed to be able to produce the maximum of what is learned. Finally, Reflection where students are given the opportunity to be able to reflect on what has been learned and the extent of the theory of scientific work that has been owned.

Furthermore, the results of the student self-concept assessment reached a good category when attending PTK learning in the tutorial class. This means that the self-concept of students has a good increase in the application of the Task Based Language Teaching method specifically using development teaching materials. This proves that the application of the Task Based Language Teaching method runs smoothly and according to what is expected. Then the motivation of students in following the tutorial after being applied to the Task Based Language Teaching method has increased motivation in tutorial learning and was more enthusiastic in following the tutorial. In this case the motivation of students in designing scientific articles, composing titles, making abstracts or essays that attract readers to read them more deeply. Furthermore they feel confident in placing their PTK research results that are worthy of publication both online and in print. 


\section{CONCLUSION AND SUGGESTION}

\section{Conclusion} follows:

Based on the results of the study, we draw some conclusions as

1. The validation results show that the application of the Task Based Language Teaching method specifically uses teaching materials and learning devices that are used in classroom tutorial teaching taking into account the results of validation, namely conformity to concept indicators, content feasibility indicators, presentation indicators, and competency indicators with RATs and The SAT is available along with the tutorial learning module Scientific Writing Techniques.

2. Self-concept of students who are good at participating in learning Scientific Writing Techniques in the tutorial class. This means that students' self-concept has a good increase and reaches a percentage above $70 \%$ in the application of the Task Based Language Teaching method specifically using teaching materials. This proves that the application of the Task Based Language Teaching method runs smoothly and according to what is expected.

3. The average value of students increases which can be seen from the pre test results of $70 \%$ to $85 \%$ in the results of the test post. These results indicate that the application of the Task Based Language Teaching method improves thinking skills and understanding of scientific article writing uploaded online.

\section{Suggestion}

UPBJJ tutors should be able to apply the Task Based Language Teaching method to other subjects so that the development of interesting tutorial learning is created and stimulates a positive response in UPBJJ students.

\section{REFERENCES}

Arikunto, S. (2009). Prosedur Penelitian: Suatu Pendekatan Praktek (5th ed). Jakarta: PT Rineka Cipta.

Boardman, C. A. (2002). Writing to Communicate Paragraphs and Essays (2nd ed). New York: Longman. 
Ellis, Rod. (2003). Task-Based Language Learning and Teaching. Oxford: Oxford University Press.

Haryanto, A. G., et al. (2000). Metode Penulisan dan Penyajian Karya Ilmiah: Buku Ajar untuk Mahasiswa. Jakarta: EGC.

Hardini, T. I. (2006). Penilaian Kemampuan Menulis Mahasiswa dengan Model Writing Workshop Melalui Internet dalam Jurnal Babasa dan Sastra. Bandung: FPBS UPI.

Hatip, F. (2005). Task-Based Language Learning. Retrieved on March 20th, /2018 from http://www.yde.yildiz.edu.tr/uddo /belgeler/incaFundaHatip-TBL.htm.

Hyland, K. (2004). Genre and Second Language Writing. USA: The University of Michigan Press.

Nunan, D. (2005). Design Task for the Communication Classroom. Cambridge: Cambridge University Press.

Oxford, R. (2006). Task-Based Language Teaching and Learning. ASLAN EFL Journal: English Language Teaching and Research Articles, 8(3), 1-18.

Richard, C., \& Rodgers, T. (2001). Approaches and Methods in Language Teaching, Second Edition. New York: Cambridge University Press.

Richards, J. C. and Renandya, W. A (2002). Methodology in Language Teaching an Anthology of Current Practice. Cambridge: Cambridge University Press.

Sugiyono. (2009). Metode Penelitian Pendidikan Pendekatan Kuantitatif, Kualitatif, dan R \& D. Bandung: Alfabeta.

Sugiyono. (2011). Metode Penelitian Pendidikan (Pendekatan Kualitatif, Kuantitatif, dan R\&D). Bandung: Alfabeta. 